\title{
Hubungan kadar hemoglobin dengan fungsi kognitif, kualitas tidur, dan lama rawat inap pasien lanjut usia di RSUP Prof. Dr. R. D. Kandou Manado
}

\author{
${ }^{1}$ Prastika C. Palawe \\ ${ }^{2}$ Linda W. A. Rotty \\ ${ }^{1}$ Kandidat Skripsi Fakultas Kedokteran Universitas Sam Ratulangi Manado \\ ${ }^{2}$ Bagian Ilmu Penyakit Dalam RSUP Prof. DR. R. D. Kandou Manado \\ Email: prastikapalawe12067@yahoo.co.id
}

\begin{abstract}
One of the benchmarks to evaluate nations' development is its life expectancy. Indonesian life expectancy is increasing along with its standards of living and health care. However, it results an increasing number of elderly patients with their multipathology characteristics. This study aimed to obtain the correlation between hemoglobin level (X) with cognitive function $\left(\mathrm{Y}_{1}\right)$, sleeping quality $\left(\mathrm{Y}_{2}\right)$ and length of stay $\left(\mathrm{Y}_{3}\right)$ among elderly patients in Department of Internal Disease Geriatric Division at Prof. Dr. R. D. Kandou Hospital Manado period January 2013 to December 2014. This study was conducted on 180 elderly patients (according to the database). This study used secondary data obtained from the medical records. The correlation test Spearman Rank showed that the relationship between hemoglobin level and cognitive function had an $r$ value $=0.004$ and a $p$ value sig $=0.957$. The correlation between hemoglobin level and sleeping quality had an $\mathrm{r}$ value $=-0.023$ and a $\mathrm{p}$ value sig $=$ 0.754 . The correlation between hemoglobin and length of stay had an $r$ value $=-0.177$ and a $p$ value sig $=0.018$. Conclusion: There was no correlation between hemoglobin level and cognitive function as well as sleeping quality. There was a very weak negative correlation between hemoglobin level and length of stay of elderly patients at Prof. Dr. R. D. Kandou Hospital Manado.
\end{abstract}

Keywords: hemoglobin level, cognitive function, sleeping quality, length of stay

\begin{abstract}
Abstrak: Salah satu tolak ukur kemajuan suatu bangsa seringkali dilihat dari harapan hidup penduduknya. Usia harapan hidup orang Indonesia semakin meningkat seiring dengan meningkatnya taraf hidup dan pelayanan kesehatan dengan konsekuensi meningkatnya jumlah pasien lanjut usia dengan karakteristik multipatologi. Penelitian ini bertujuan untuk memperoleh analisis hubungan kadar hemoglobin $(\mathrm{X})$ dengan fungsi kognitif $\left(\mathrm{Y}_{1}\right)$, kualitas tidur $\left(\mathrm{Y}_{2}\right)$ dan lama rawat inap $\left(\mathrm{Y}_{3}\right)$ pasien lanjut usia di Bagian Ilmu Penyakit Dalam Divisi Geriatri RSUP Prof. DR. R. D. Kandou Manado periode Januari 2013 sampai Desember 2014. Penelitian ini dilakukan pada 180 pasien lanjut usia (berdasarkan database). Pengambilan data sekunder (retrospektif) diperoleh dari catatan medik. Uji korelasi Spearman Rank untuk analisis hubungan kadar hemoglobin dan fungsi kognitif mendapatkan nilai $r=0,004$ dan nilai $\mathrm{p}$ sig $=0,957$. Hubungan kadar hemoglobin dan kualitas tidur mendapatkan nilai $\mathrm{r}=$ 0,023 dan nilai $\mathrm{p}$ sig $=0,754$. Hubungan kadar hemoglobin dengan lama rawat inap mendapatkan nilai $r=-0,177$ dan nilai $p$ value sig $=0,018$. Simpulan: Pada pasien lanjut usia di RSUP Prof. Dr. R. D. Kandou Manado tidak terdapat hubungan antara kadar hemoglobin dengan fungsi kognitif dan kualitas tidur. Terdapat hubungan negatif yang sangat lemah antara kadar hemoglobin dengan lama rawat inap pasien.
\end{abstract}

Kata kunci: kadar hemoglobin, fungsi kognitif, kualitas tidur, lama rawat inap. 
Salah satu tolak ukur kemajuan suatu bangsa seringkali dilihat dari harapan hidup penduduknya. Usia harapan hidup orang Indonesia semakin meningkat seiring dengan semakin meningkatnya taraf hidup dan pelayanan kesehatan. Kendali tersebut membawa dampak terhadap peningkatan jumlah populasi lanjut usia (lansia). Indonesia sebagai suatu negara berkembang, dengan perkembangannya yang cukup baik, makin tinggi harapan hidupnya diproyeksikan dapat mencapai lebih dari 70 tahun. ${ }^{1}$ Pada tahun 2000 jumlah orang usia lanjut di proyeksikan sebesar 7,28\% dan pada tahun 2020 sebesar 11,34\%. Dari data USA-Bureau of the consensus, bahkan Indonesia diperkirakan akan mengalami pertambahan warga lansia terbesar seluruh dunia, antara tahun 1990-2025, yaitu sebanyak 414\%. ${ }^{2}$ Konsekuensi peningkatan jumlah populasi lanjut usia ialah meningkatnya jumlah pasien lanjut usia dengan karakteristik multipatologi. ${ }^{3}$

Salah satu penyakit yang sering diderita orang lansia yaitu anemia yang merupakan kelainan hematologi yang paling banyak dijumpai pada lansia. Prevalensinya meningkat secara signifikan seiring dengan bertambahnya usia yaitu setelah usia 75 tahun. ${ }^{4-6}$

Pengaruh kelainan hematologi tersebut dapat memicu terganggunya status fungsional, dan yang paling menojol pada pasien lansia ialah penurunan fungsi kognitif. WHO mencatat penurunan fungsi kognitif lansia diperkirakan pada 121 juta manusia; dari jumlah itu 5,8 \% laki-laki dan $9,5 \%$ perempuan. $^{7}$

Masalah lain yang sering muncul pada lansia dengan penurunan kadar hemoglobin atau anemia adalah gangguan tidur dan kualitas tidur. Seorang usia lanjut akan membutuhkan waktu lebih lama untuk masuk tidur dan mempunyai lebih sedikit waktu tidur nyenyaknya. Dari penelitian The Gallop Organization didapatkan 50\% penduduk Amerika pernah mengalami sulit tidur dan $12 \%$ mengatakan sering sulit tidur. ${ }^{8,9}$
Konsekuensi lainnya yang dapat terjadi ialah bertambahnya lama rawat inap (length of stay, LOS) yang merupakan salah satu indikator pelayanan di rumah sakit untuk mengukur efisiensi pelayanan rumah sakit tersebut. Rawat inap di rumah sakit yang memanjang tidak hanya meningkat-kan biaya perawatan dan mengurangi efisiensi pelayanan rumah sakit, tapi juga berkaitan dengan komplikasi lainnya seperti infeksi nosokomial, imobilitas, dekubitus, dan deep vein thrombosis (DVT) yang memperburuk kualitas hidup pasien. ${ }^{10,11}$

\section{METODE PENELITIAN}

Jenis penelitian ini retrospektif analitik. Penelitian ini menganalisis hubungan antara variabel penelitian, melalui data pasien yang datang berobat dan menjalani rawat inap di Bagian Ilmu Penyakit Dalam RSUP Prof. Dr. R. D. Kandou Manado periode Januari 2013 sampai Desember 2014. Penelitian ini menggunakan teknik pengambilan data sekunder yang diperoleh dari catatan medik pasien lanjut usia di Bagian Ilmu Penyakit Dalam Divisi Geriatri RSUP Prof. Dr. R. D. Kandou Manado.

\section{HASIL PENELITIAN}

Secara umum didapatkan bahwa sampel penelitian (pasien berdasarkan database) yang berjenis kelamin laki-laki 89 pasien (49,4\%), yang berjenis kelamin perempuan 91 pasien (50,6\%). Nilai terendah umur pasien 60 tahun dan tertinggi 95 tahun sehingga didapatkan rerata 69,76 dengan nilai simpang baku 6,628. Untuk kadar hemoglobin nilai terendah 3 dan nilai tertinggi 17, sehingga didapatkan rerata 10,62 dengan nilai simpang baku 2,956. Untuk nilai MMSE didapatkan nilai terendah 3 sedangkan nilai tertinggi 30, sehingga didapatkan rerata 24,46 dengan simpang baku 5,952. Untuk nilai IRS didapatkan nilai terendah 0 dan nilai tertinggi 19 sehingga didapatkan rerata 8,71 dengan simpang baku 3,715. Dan untuk nilai LOS didapatkan nilai terendah 2 dan nilai tertinggi 37, sehingga 
didapatkan rerata 10,13 dengan nilai simpang baku 6,608 (Tabel 1).

Tabel 1. Karakteristik Umum Sampel Penelitian

\begin{tabular}{cccccc}
\hline Variabel & N & Min & Max & Mean & SD \\
& & & & & \\
\hline Umur & 180 & 60 & 95 & 69,76 & 6,628 \\
Gender & & & & & \\
\hline L & 89 & & & & \\
P & 91 & & & & \\
\hline Hb & 180 & 3 & 17 & 10,62 & 2,956 \\
MMSE & 180 & 3 & 30 & 24,46 & 5,925 \\
IRS & 180 & 0 & 19 & 8,71 & 3,715 \\
\hline LOS & 180 & 2 & 37 & 10,13 & 6,608 \\
\hline
\end{tabular}

Berdasarkan hasil penelitian, didapatkan sampel dengan kategori lanjut usia/elderly (60-74 tahun) sebanyak 132 pasien (73\%) kategori lanjut usia tua/old ( 75-90 tahun) sebanyak 46 pasien (26\%) dan kategori usia sangat tua/very old ( $>90$ tahun) sebanyak 2 pasien (1\%) (Gambar 1).

Berdasarkan hasil penelitian, didapatkan 12 pasien (7\%) menderita anemia berat, 39 pasien (22\%) menderita anemia sedang, 37 pasien (20\%) menderita anemia ringan dan 92 pasien (51\%) tidak mengalami anemia atau memiliki kadar hemoglobin dalam rentang nilai normal (Gambar 2).

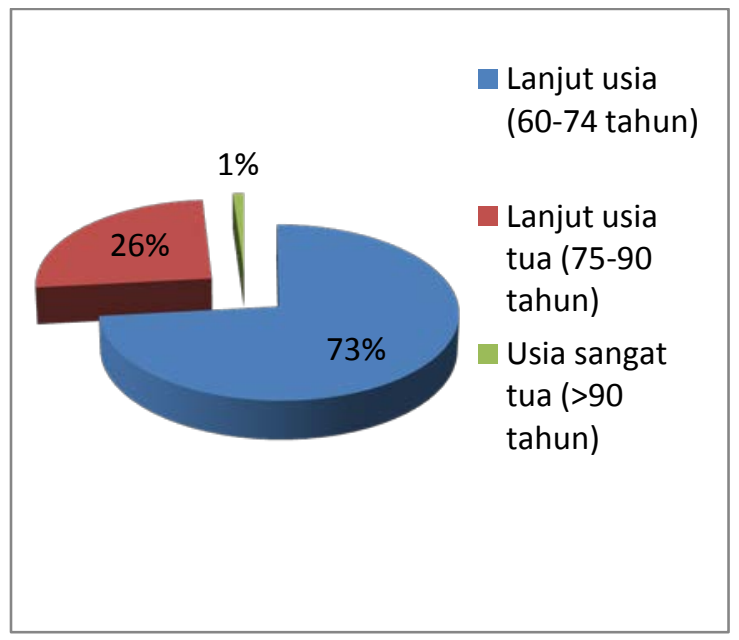

Gambar 1. Distribusi Sampel Bedasarkan Kelompok Umur

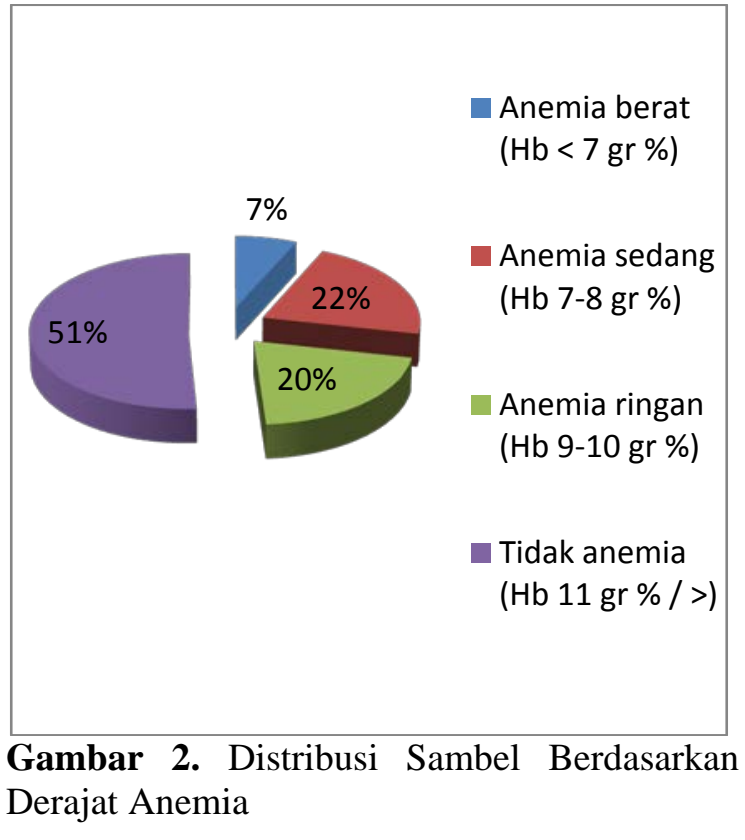

Berdasarkan hasil penelitian, didapatkan 3 pasien (2\%) mengalami gangguan kognitif berat, 21 pasien (12\%) mengalami gangguan kognitif sedang, 35 pasien (19\%) mengalami gangguan kognitif ringan dan 121 pasien (67\%) dengan fungsi kognitif normal (Gambar 3).

Berdasarkan hasil penelitian, didapatkan 56 pasien (31\%) memiliki kualitas tidur dalam rentang nilai normal, 97 pasien (54\%) mengalami insomnia ringan, 26 pasien (14\%) mengalami insomnia sedang dan 1 pasien (1\%) mengalami insomnia berat (Gambar 4).

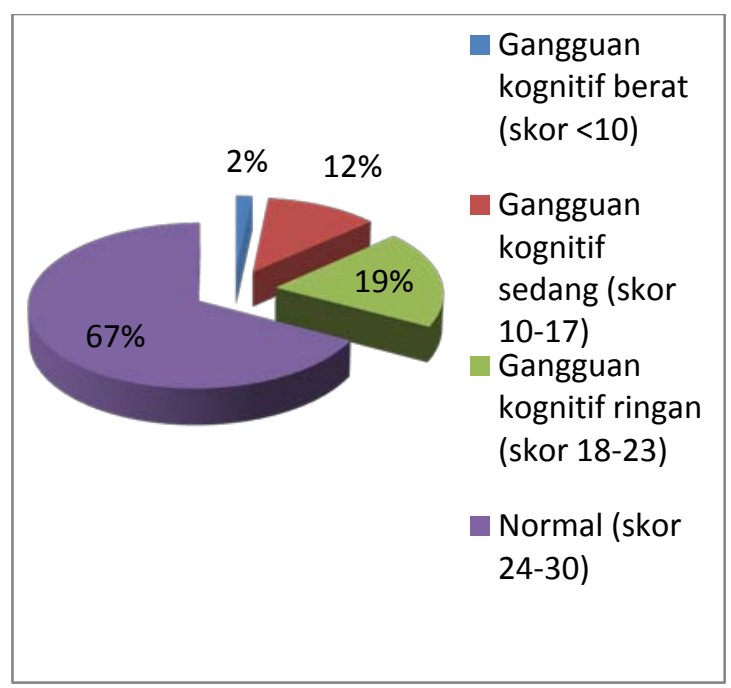

Gambar 3. Distribusi Sampel Berdasarkan Derajat Gangguan Fungsi Kognitif 
Palawe, Rotty: Hubungan kadar hemoglobin dengan fungsi kognitif, ...

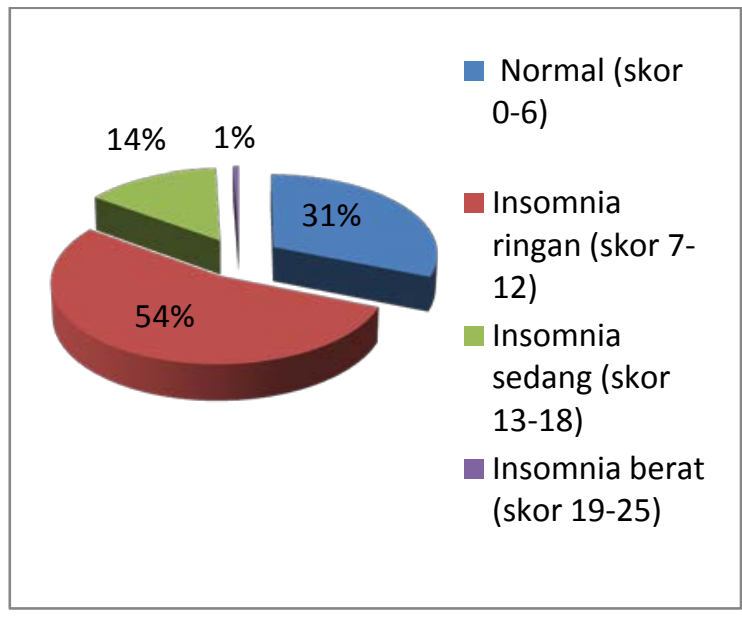

Gambar 4. Distribusi Sampel Berdasarkan Derajat Insomnia

Berdasarkan analisis data yang dilakukan untuk menguji hubungan kadar hemoglobin (X) dengan fungsi kognitif $\left(\mathrm{Y}_{1}\right)$ didapatkan nilai $\mathrm{r}=0,004$ dan nilai $\mathrm{p}$ value sig = 0,957 (Gambar 5).

Berdasarkan analisis data yang dilakukan untuk menguji hubungan kadar hemoglobin $(\mathrm{X})$ dengan kualitas tidur $\left(\mathrm{Y}_{2}\right)$ didapatkan nilai $r=-0,023$ dan nilai $\mathrm{p}$ value sig $=0,754$ (Gambar 6).

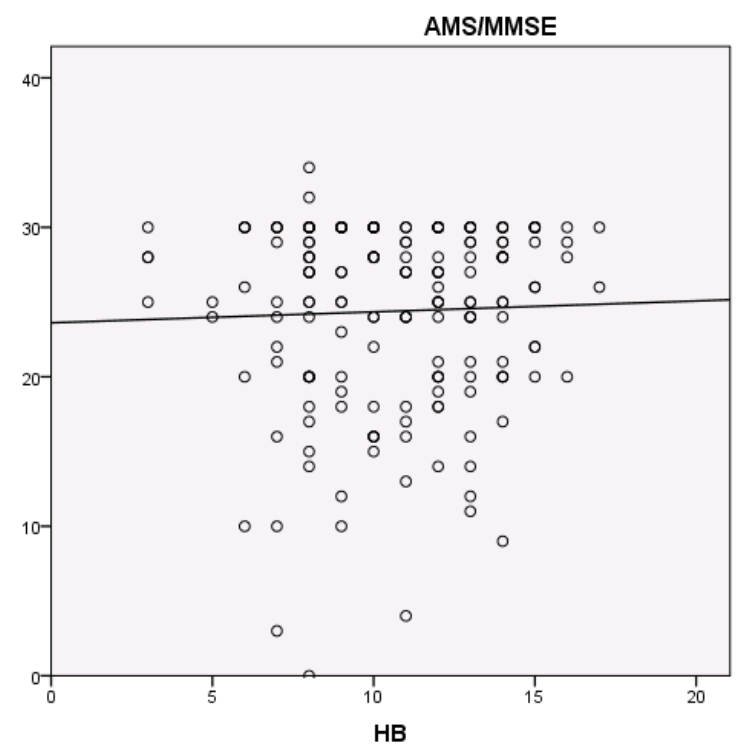

Gambar 5. Hubungan kadar hemoglobin dengan fungsi kognitif

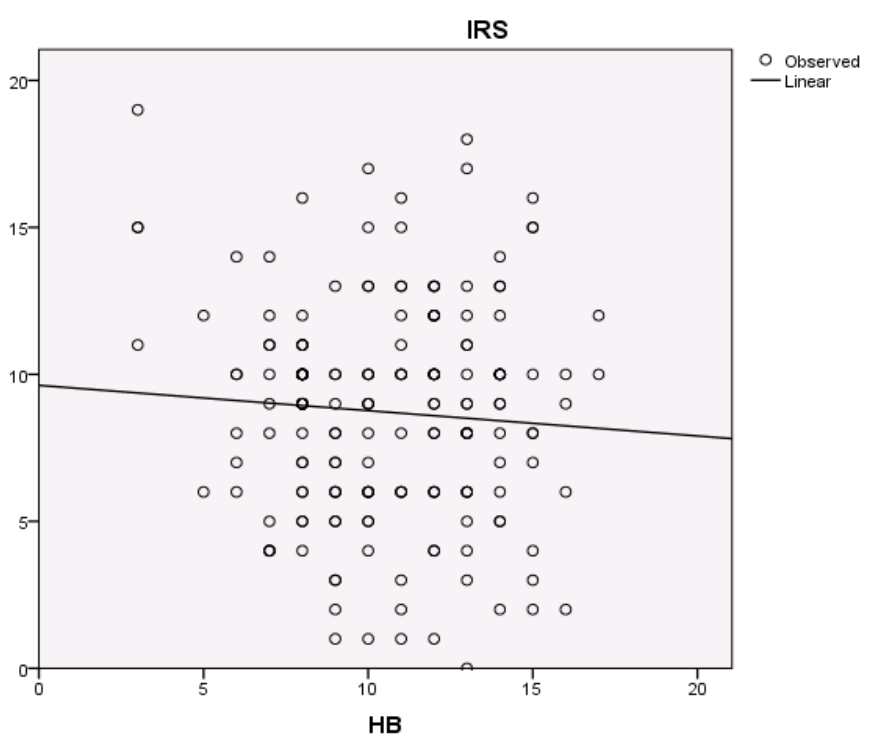

Gambar 6. Hubungan Kadar Hemoglobin dengan Kualitas Tidur

Berdasarkan analisis data yang dilakukan untuk menguji hubungan kadar hemoglobin (X) dengan lama rawat inap $\left(\mathrm{Y}_{3}\right)$ didapatkan nilai $\mathrm{r}=-0,177$ dan nilai $\mathrm{p}$ value sig $=0,018$ (Gambar 7).

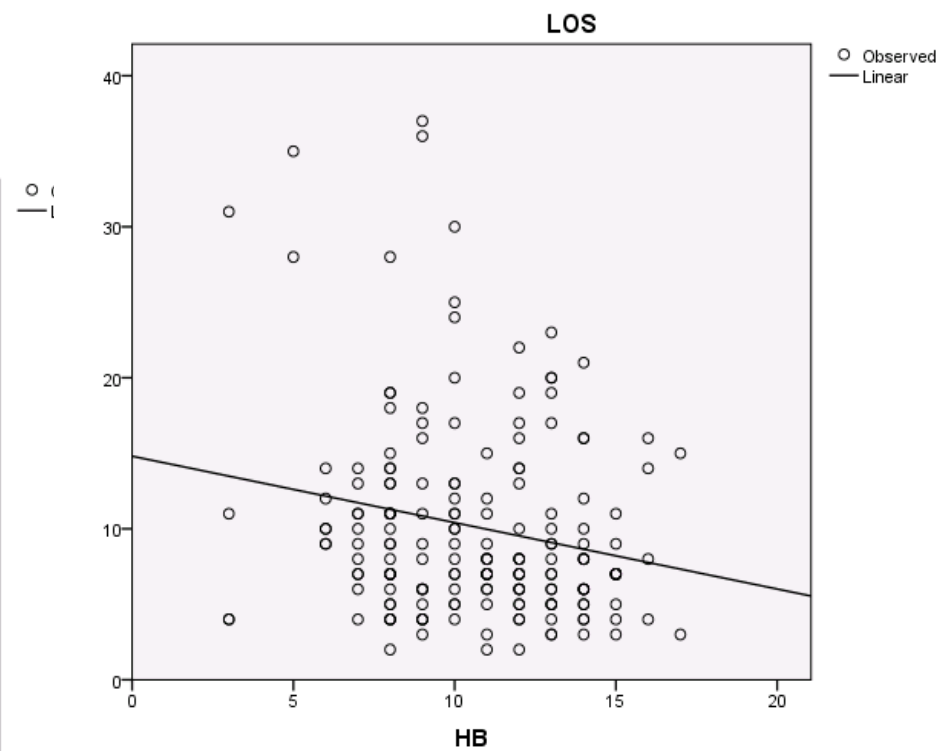

Gambar 7. Hubungan Kadar Hemoglobin dengan Lama Rawat Inap

\section{BAHASAN}

Penelitian ini menyerupai penelitian sebelumnya yang telah dilakukan oleh Firdaus tentang hubungan kadar hemoglobin dengan fungsi kognitif lansia di Panti Werdha Wening Wardoyo 
Semarang. Penelitian Firdaus menggunakan metode penelitian kuantitatif non eksperimental dengan pendekatan deskriptif korelasional dan menggunakan uji korelasi Spearman Rank sebagai alat uji statistik. Dalam penelitiannya, Firdaus menemukan adanya hubungan antara kadar hemoglobin dengan fungsi kognitif lansia dengan nilai $r=0,278$ dan $p$ value sig $=0,049 .{ }^{12}$ Hasil yang didapatkan dalam penelitian ini berdasarkan uji korelasi Spearman Rank didapatkan nilai $r=0,004$ dan nilai $\mathrm{p}$ value sig $=0,957$ (tidak signifikan) artinya dalam penelitian penulis didapatkan bahwa tidak terdapat hubungan antara kadar hemoglobin dengan fungsi kognitif pasien lanjut usia di RSUP Prof. Dr. R. D. Kandou Manado. Hal tersebut disebabkan adanya berbagai faktor yang dapat mempengaruhi fungsi kognitif pada pasien lanjut usia, diantaranya faktor usia, jenis kelamin, pendidikan, riwayat penyakit, lingkungan sosio-kultural, gizi dan aktivitas fisik. Faktor-faktor tersebut dapat memengaruhi hasil pemeriksaan fungsi kognitif yang diukur menggunakan Mini Mental State Examination (MMSE).

Penelitian terdahulu yang juga berkaitan dengan penelitian ini ialah penelitian Rompas et $\mathrm{al}^{13}$ tentang hubungan kadar hemoglobin dengan kualitas tidur pasien penyakit ginjal kronik di Poli ginjal dan hipertensi di RSUP Prof. Dr. R. D. Kandou Manado. Rompas et $\mathrm{al}^{13}$ menggunakan kuesioner kualitas tidur Pittsburgh sleep quality index (PSQI) dan kadar hemoglobin yang dilihat pada rekam medik pasien satu bulan terakhir sebagai sumber data dan metode penelitian survei analitik dengan pendekatan potong lintang. Hasil penelitian menunjukkan dengan uji Chi Square didapatkan $\mathrm{p}$ value $=0,003<$ 0,005 . Hal ini menunjukkan terdapat hubungan bermakna antara kadar hemoglobin dengan kualitas tidur pasien penyakit ginjal kronik di poli ginjal dan hipertensi BLU RSUP Prof. Dr. R. D. Kandou Manado. Pada penelitian ini, berdasarkan hasil uji korelasi Spearman
Rank yang dilakukan didapatkan nilai $\mathrm{r}=$ - 0,023 dan nilai $\mathrm{p}$ value sig $=0,754$ (tidak signifikan) artinya tidak terdapat hubungan antara kadar hemoglobin dengan kualitas tidur pasien lanjut usia di RSUP Prof. Dr. R. D. Kandou Manado. Hal ini disebabkan karena adanya berbagai fakor yang dapat memengaruhi kualitas tidur setiap orang, diantaranya stres dan kecemasan yang berlebihan, penyakit, kurang olahraga, pola makan yang buruk, konsumsi alkohol, kafein, dan nikotin, keadaan ramai, perbedaan suhu, perubahan lingkungan sekitar, efek samping pengobatan. ${ }^{14}$

Penelitian selanjutnya yang berkaitan dengan penelitian ini ialah penelitian Gunawan et $\mathrm{al}^{14}$ tentang hubungan kadar hemoglobin dengan lama rawat diare pada anak di RSUP Prof. Dr. R.D Kandou. Penelitian Gunawan et al menggunakan pasien anak penderita diare sebagai subjek penelitian, sedangkan penelitian ini menggunakan pasien lansia di RSUP Prof Kandou Malalayang sebagai subjek penelitian. Hasil yang oleh Gunawan et al berdasarkan hasil uji korelasi Pearson nilai $r=-0,415$ dan nilai $p$ value sig $=0,003$ yang artinya, terdapat hubungan negatif yang sangat bermakna antara kadar hemoglobin dengan lama rawat inap. ${ }^{14}$ Penelitian tersebut sesuai dengan penelitian yang dilakukan penulis. Berdasarkan hasil uji korelasi Spearman Rank didapatkan nilai $\mathrm{r}=-0,177$ dan nilai $\mathrm{p}$ value sig $=$ 0,018. Hal ini menyatakan terdapat hubungan yang lemah antara kadar hemoglobin dengan lama rawat inap pasien lanjut usia di RSUP Prof. DR. R. D. Kandou Manado, yang berarti semakin tinggi kadar hemoglobin semakin cepat perawatannya.

\section{SIMPULAN}

Dari hasil penelitian terhadap pasien lanjut usia di RSUP Prof. DR. R. D. Kandou Manado periode Januari 2013 sampai Desember 2014dapat disimpulkan bahwa:

1. Tidak terdapat hubungan antara kadar hemoglobin dengan fungsi kognitif dan 
kualitas tidur

2. Terdapat hubungan negatif yang sangat lemah antara kadar hemoglobin dengan lama rawat inap

\section{SARAN}

1. Perlu dilakukan penanganan yang lebih optimal secara komprehensif bagi pasien geriatri yang memiliki karakteristik multipatologi agar dapat meminimalkan berbagai risiko yang dapat memperberat gangguan fungsi dan penyakit yang dialami dan dapat meningkatkan kualitas hidup pasien.

2. Disarankan agar pemeriksaan kadar hemoglobin dijadikan pemeriksaan rutin untuk pasien lanjut usia untuk mengontrol berbagai risiko yang dapat terjadi akibat rendahnya kadar hemoglobin dalam darah.

\section{UCAPAN TERIMA KASIH}

Ucapan terima kasih ditujukan kepada dr. Cecilia Hendratta, Sp.PD, dr. Efata B. Polii, Sp.PD dan dr. Veny Mandang, Sp.PD yang telah memberi masukan dalam penulisan artikel ini.

\section{DAFTAR PUSTAKA}

1. Darmojo BR. Teori proses menua. In: Darmojo BR, Martono HH, editors. Buku ajar geriatri (5th ed). Jakarta: Badan penerbit FKUI, 2014: p. 7.

2. Darmojo BR. Demografi dan epidemiologi populasi lanjut usia. In: Darmojo $\mathrm{BR}$, Martono $\mathrm{HH}$, editors. Buku ajar geriatric (5th ed). Jakarta: Balai Penerbit FKUI, 2014; p. 40.

3. Seojono H. Pedoman pengelolaan kesehatan geriatri untuk dokter dan perawat. Jakarta: Pusat informasi penerbitan Bagian Ilmu Penyakit Dalam FKUI, 2010.

4. Johnson A, Dorshkind A. Stromal cell in myeloid and lymphoid long-term bone marrow cultures can support multiple hemopoietic lineages and modulate their production of hemopoietic growth factors. Kruger A, editor. The limits of normality in elderly patients. Baillie're's Clinical haematology, 2009; p. 1: 271.
5. Supardiman I, Fadjari H. Anemia pada penyakit kronis. In: Suyono W, Setyohadi B, Alwi I, Setyadi S, editors. Buku ajar ilmu penyakit dalam. Jakarta: Balai penerbit FKUI, 2012; p. 651-52.

6. Guyton AC, Hall JE. Sel-sel darah, imunitas dan pembekuan darah. In: Rachman LY, Hartanto H, Novrianti A, Wulandari N, editors. Buku ajar fisiologi kedokteran (11th ed). Jakarta: EGC; p. 20.

7. Nehlig A. Is caffeine a cognitive enhancer. Journal of Alzheimer disease.

8. Karjono BJ, Rahayu RA. Gangguan tidur pada lansia. In: Boedhi DR, Martono $\mathrm{HH}$, editors. Buku ajar geriatric (5tg ed). Jakarta: Badan penerbit FKUI, 2014; p. 319.

9. Darmojo BR. Gangguan tidur pada usia lanjut. In: Darmojo BR, Martono $\mathrm{HH}$, editors. Buku ajar geriatric (5th ed). Jakarta: Balai penerbit FKUI, 2014. p. 319.

10.Mark R, Chassin M. Their relationship to health outcome. Journal of variation in hospital length of stay. 2008.

11.Hunter B, Carry $\mathbf{W}$, editors. Factors influencing length of stay in hospital. New York, 2007.

12.Firdaus R. Hubungan Kadar Hemoglobin dengan Fungsi Kognitif Lansia di Panti Werdha Wening Wardoyo Semarang. Undergraduate thesis, Universitas Diponegoro. Available from: URL: http:// keperawatan.undip.ac.id. [cited December 10, 2015].

13. Rompas AB, Tangka J, Rottie J. Hubungan kadar hemoglobin dengan kualitas tidur pasien penyakit ginjal kronik di poli ginjal dan hipertensi RSUP Prof. DR. R. D. Kandou Manado. Available from: http://ejournal.unsrat.ac.id/index./ [cited December 10, 2015].

14.Gunawan KN, Mantik MF, Manoppo JI. Hubungan kadar hemoglobin dengan lama rawat diare pada anak di RSUP Prof. Dr. R. D. Kandou Manado. Available from: http://ejournal.unsrat.ac.id/index.php [cited December 10, 2015]. 